\title{
Characteristics of Eucheuma cottonii waste from East Malaysia: physical, thermal and chemical composition
}

\begin{abstract}
The aim of this paper was to examine the characteristics of Eucheuma cottonii waste in order to analyse its potential as renewable material. The morphology of Eucheuma cottonii (raw and wastes) was investigated through scanning electron microscopy (SEM), the thermal behaviour through thermogravimetric analysis (TGA) and the physical properties through FTIR, XRD, gas pycnometer, particle size analyser, water absorption and moisture content analysis. The chemical compositions were determined by using acid detergent fibre (ADF), neutral detergent fibre (NDF) and acid detergent lignin (ADL) analysis. It was found that Eucheuma cottonii wastes have better thermal stability, higher crude fibre content, lower moisture content and similar density to the raw Eucheuma cottonii, which suggests that these biomass wastes have good potential as renewable filler material.
\end{abstract}

Keyword: Biomass waste; Eucheuma cottonii; Kappaphycus alvarezii; marine red algae; Rhodophyta; Seaweed 